Vietnam Academy of Science and Technology
Vietnam Journal of Earth Sciences
(VAST) $/ /$ www.vjs.ac.vn/index.php/jse

\title{
Identification of geothermal reservoir from exploration data in the Bang hot spring area, Central Vietnam
}

\author{
Tran Anh Vu, Doan Van Tuyen, Tran Tuan Anh, Dinh Van Toan, Lai Hop Phong* \\ Institute of Geological Sciences, VAST, Hanoi, Vietnam
}

Received 05 April 2017. Accepted 02 August 2017

\begin{abstract}
Worldwide literature shows that the potential for electricity generation of every geothermal source is depended on the local condition, so the exploration phase is an important step in the geothermal power development to identify the site, structural feature and temperature parameters of a geothermal system-reservoir. The paper presents some results of the first experiment carried out by using a combination of geological, geochemical, geophysical methods, and temperature measurements in shallow drilling hole (depth $250 \mathrm{~m}$ ) were applied for investigation in the Bang hot water spring area, Quang Binh province, during the period from 2012 to 2015. The location and structural feature of geothermal reservoir identified by the resistivity model obtained from the magneto-telluric survey and geochemical analysis was a good consistency with the existent reservoirs of a typical hydro-geothermal system of magmatic origin. The temperature gradient and heat flow at the shallow drilling hole are reached $4.1{ }^{\circ} \mathrm{C} / 100 \mathrm{~m}$ and $83.4 \mathrm{~mW} / \mathrm{m}^{2}$, respectively. The reservoir temperatures estimated by both geochemical thermometer and temperature modeling are varied in a range $167-200^{\circ} \mathrm{C}$ at the depth $>2 \mathrm{~km}$. The obtained results allow to determine the suitable location for test drilling to the reservoir and to propose for the next phase of the Geothermal Program in the area.
\end{abstract}

Keywords: Bang hot spring, geochemical thermometer, hydrothermal source, magma, magnetotelluric method, geothermal reservoir.

(C)2017 Vietnam Academy of Science and Technology

\section{Introduction}

Utilization of geothermal energy, one of the renewable power types is a great concern in the world. Until 2014 the capacity of electrical power generated from geothermal sources was reached $12,635 \mathrm{Mw}$ in 24 countries (Bertani, 2015). Comparison of characteristic parameters of site distribution, chemical composition, geological condition, stratigraphic and geothermal regime, etc. of hot water sources in Vietnam with several world-

"Corresponding author, Email: laihopphong@yahoo.co.uk wide representative power generating geothermal sources found was a number of hydro-geothermal systems in the Central Region matching the criteria needed for exploration. The geothermal water is characterized by the peripheral reservoir composition. The geothermal springs are distributed in the regions covered by Neogene-Quaternary, including Holocene basaltic formations in Truong Son, Kon Tum and Lam Dong terrains (Phan $\mathrm{Cu}$ Tien, 1992; Nguyen Hoang et al., 1996, Tran Van Tri, 2004), characterized by high heat flow anomaly $>80 \mathrm{~mW} / \mathrm{m}^{2}$ (Dinh Van Toan et 
al., 1996; He Lijuan, 1999; Tran Huyen et al., 1999).

Since the 1980s, Vietnamese and foreign researchers, as well as investors (ORMAT), have reached a conclusion that geothermal resources in Vietnam are favorable for the development of energy generation, but additional surveys are needed (Flynn, 1997). To solve this problem, in 2012 under the financial support by the National Program "Scientific Research and Technology for disaster prevention, environmental protection and rational use of natural resources" coded $\mathrm{KC} 08 / 11-15$, for the first time in Vietnam, the exploration phase was approved and related works were conducted during the period from 2012 to 2015 in the Bang hot spring area of Quang Binh province. The important task of the exploration was to understand the distribution, structural and temperature parameters of the geothermal system. A combination of geological, geophysical, geochemical techniques was employed among the other applied geophysical methods such as magnetotelluric survey, which played one of the key roles. The borehole temperature measurements were also conducted.

The geological map and distribution scheme of geothermal springs of Vietnam are presented in Figure 1. The chemical compositions and temperatures of hot water samples taken from 287 sites are reported in the monograph "Geothermal resource in Vietnam and perspectives of their use for energy purposes" (Vo Cong Nghiep, 1998).

The estimation of electricity generation potential of geothermal systems can be realized by comparing their structural and geothermal parameters obtained from the exploration and analytical data in this study with those parameters characterized for a Worldwide conceptual model of a hydrogeothermal system and the geothermal fields used for electricity generation in different countries nowadays (Di Pippo, 2012; IGA report, 2013). In this case, a simple method such as experimental graphic (GeothermEx,
2004; Chandrakharam, 2008) using the structural elements, temperature and flow rate of geothermal fluid of reservoir can be applied for the estimation.

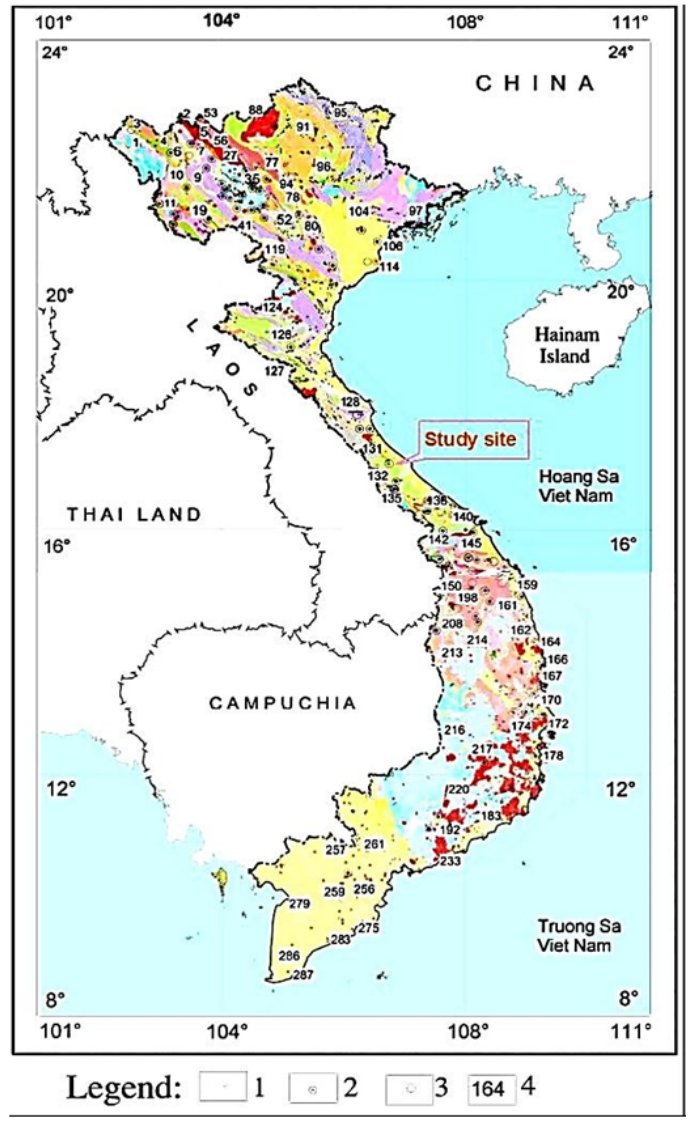

Figure 1. Manifestation of geothermal resource on the geological map of Vietnam

Legend: Temperature of water: 1) $30-40^{\circ} \mathrm{C}$; 2) $41-60^{\circ} \mathrm{C}$; 3) $>61^{\circ} \mathrm{C}$; 4) Index of water site

\section{Survey data in the Bang hot spring area}

The exploration was conducted in the area of Bang hot water spring and its adjacent, where the flow rate of the exposed hot water source measured on the surface is $401 / \mathrm{s}$ with water temperature reached $100^{\circ} \mathrm{C}$ (the highest temperature among the geothermal sources in Vietnam). The detail geological condition of the area obtained in this study is presented in Figure 2. Some parameters such as physical 
properties, chemical compositions, and hot water utilities for this site were partly described in the previous studies (Vo Cong Nghiep, 1998). This hot water source also is one of the selected locations of the ORMAT Group (US) for investment with the expectation to develop electricity energy (Flynn, 1997).

\subsection{Methodology}

The exploration conducted in the area of Bang and surroundings was involved geological and tectonic surveys for getting the information about stratigraphic features, lithological composition of geological formations, magmatic activities, distribution of faults and its recent tectonic activities (following the guide to resource data collection, analysis, and presentation for Geothermal projects and IGA report, 2013). These elements are closely related to the condition and mechanism of appearance and existence of geothermal sources.

To understand the physical nature of the exposed water source, the geochemical analysis of dissolved concentration of the major and trace elements was carried out on 20 water samples collected in the surroundings of hot water spring including hot geothermal water, warm water, and cold water. The analysis for $18 \mathrm{O}, 2 \mathrm{H}, 3 \mathrm{H}$ isotopes was applied for 5 samples from the hot spring and rain water. Chemical analysis of water samples was conducted at the Chemical Analysis Center at the Institute of Geological Sciences (IGS, VAST) and isotopic analysis was performed at the Nuclear Center of Rome University (Italy). The information suggestive the origin, properties of geothermal solution and temperature of the reservoir are illustrated on the chart-StanfordGW.xls Liquid Analysis _v1_Powell-2010 after input of the obtained chemical data (Powell T. and Cumming M. 2010).

The geophysical investigations were carried out using electromagnetic and seismic methods. Since the magnetotelluric (MT) survey allowed to reveal not only the distribution, deep structural features, but also the parameters related to the physical property of a geothermal system, so the method plays a key role in the exploration (Munoz, 2014). The measurements were fulfilled by MT equipment MTU2000 (made in Canada) in 43 points in the area of $2-4 \mathrm{~km}$ in radius from the Bang hot-water source. The seismic exploration in this study was mainly applied to supply additional information on the structures of the expected reservoir itself. The data collection was carried out using 150 wireless Texan seismic instruments (USA) along 4 profiles with their length varied from 8 to $11.5 \mathrm{~km}$ in the study area. The results of MT data interpretation allowed to predict the existence of a geothermal reservoir and heat supply source in the study area (Doan Van Tuyen et al., 2014; 2015). The seismic data revealed a fracture zone distributed above the MT defined a geothermal reservoir in the extension structure restricted by the 2 local sub-meridian tectonic faults (Tran Anh Vu et al., 2016). According to the results, the geophysical parameters obtained from data interpretation (mainly resistivity parameters) indicated that the structural elements of the geothermal system satisfied the worldwide conceptual model of the hydro-geothermal system from the international literature (IGA report, 2013; Munoz, 2014).

The surface geothermal survey was carried out to estimate the thermal gradient and surface heat flow, etc. For this purpose, the temperature log was performed after drilling a shallow drilling hole of $250 \mathrm{~m}$ deep created in the area of expected geothermal reservoir. Its location was chosen by using geophysical data. The geothermal conductivity of rocks was directly measured for the samples taken from the borehole and its surroundings. The temperature $\log$ was repeated after about 6 months later with the expectation to restore the geothermal regime in the borehole.

The underground temperature distribution in the area surrounding the shallow borehole was derived by modeling technique using software TOUTH2 (USA) along the MT section. The surface heat flow and geothermal 
gradient used for modeling were calculated from both the temperature data collected along the drilling hole and thermal conductiviconductivity of the rocks; the crustal structural parameters are inferred from the magnetotelluric data and collected from the previous studies (Bui Cong Que, Nguyen Kim Lap, 1992, Doan Van Tuyen et al., 2015; Dinh Van Toan et al., 2015); Other parameters such as physical properties of the environment (density, porosity) are defined from the handbooks (Truong Thu Huong, 2006; Dortman, 1984; Robertson Eugene, 1988) followed the petrologic composition of the geological formations revealed during the field survey.

Since the surveys conducted at this stage are implemented on the ground surface, the received temperature parameters of geothermal system/reservoir should only be accepted as the indications of interest.

\subsection{Result and discussion}

\subsubsection{Geological and tectonic survey}

The detail geology-geotectonic surveys conducted in this study (Figures 1,2), Bang hot spring is located in the area of NW-SE trending Khe Giua - Vinh Linh fault. The intensive right lateral strike - slip motion of this regional fault constrained by the extension stress field of subparallel direction during Late Pliocene - Quaternary time has created a favorable condition for upward movement of magmatic structures from the mantle to the crust. In consequences, the submedian extension structures were popularly developed in the region and a number of basaltic structures of Neogene Quaternary ages appeared in the region (about $8 \mathrm{~km}$ northwest from Bang hot spring, Vinh Linh). Those magmatic bodies cannot reach the surface are called intrusive structures, while some of them distributed near the surface become hidden geothermal sources. In addition, the interaction between the thermal fluid from some depth upward along the fault fractured zone with the near-surface ground water flow may be the reason of the appearance of Bang hot water spring on the surface. The age of the Neogene - Quaternary basalts estimated in the previous studies is 600,000-700,000 years for the basaltic eruptions N-Q (Phan $\mathrm{Cu}$ Tien, 1991) and 350,000 years for the QIV basalt (Nguyen Xuan Han et al., 1991). The appearance of Holocene magmatic extrusion in Gio Linh is probably related to magmatic reactivity in the Late Pliocene-Quaternary or basaltic injection occurred later, such as the ash eruption in Tro Island on the continental shelf of Binh Thuan province in 1923 (Nguyen Xuan Han et al., 1991). The intrusive bodies formed at shallow depth in those regions may have become hidden heat sources satisfying exploration conditions for geothermal electricity (Brikowski et al., 2001; Di Pippo, 2012; IGA report, 2013). In this sense, the existence close to the surface of a hot intrusive magmatic body in the Bang area is possible that can play a role as the source to supply the heat for the geothermal reservoir.

Regarding the lithology, in the Bang spring area widely spread are the following geological formations: Cambrian-Early Ordovician, Late Ordovician - Early Ssilurian ages, in which the lower part of Long Dai (O3-S1ld1-2) and A Vuong ( $\mathrm{C}-\mathrm{O}$ lav) sub-formations are composed of coarse-grained materials with high porosity (sandy, conglomerate, tuff,...). This is a favorable condition for circulating and accumulating geothermal water and initiation of streaming flow to form reservoir and clay cap. In the subsurface layer distributed are sedimentary rocks of Middle and Late Long Dai sub-formations (O3-S1ld2-3) comprising claystone and siltstone, characterized by low thermal conductivity that can play a role of water proof layer. The total thickness of these sedimentary formations is about $3 \mathrm{~km}$ (Phan Cu Tien, 1991; Tran Van Tri, 2004).

All the mentioned above elements of geology-geotectonic environment indicate a good condition for a perspective geothermal reservoir in the Bang hot spring area. 


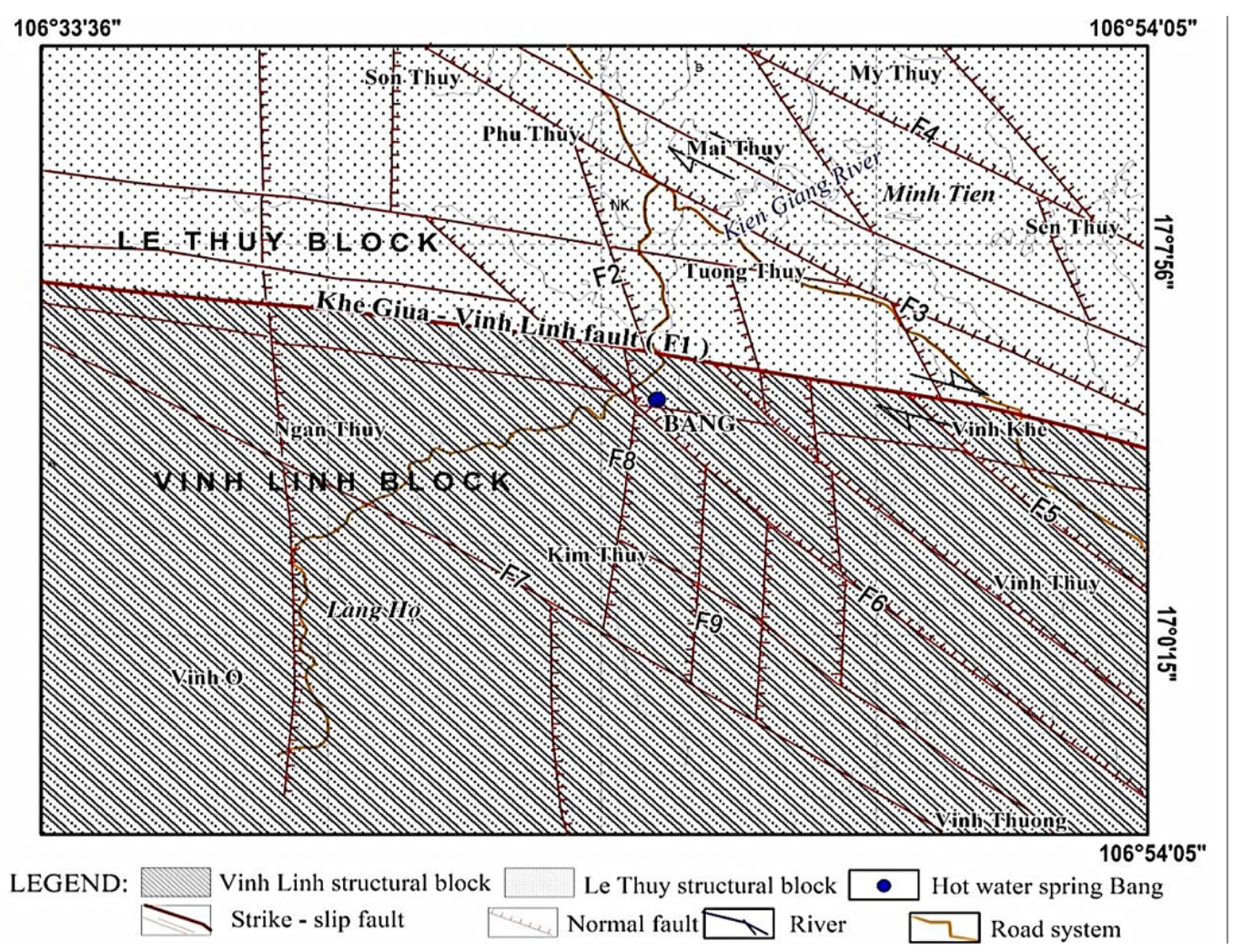

Figure 2. Geological-tectonic map in surrounded area of Bang hot spring

\subsubsection{Geochemical data}

The water samples used for chemical analysis were collected in the area of hot spring and tectonic fault zone (Figure 3).

The results of chemical and isotope analysis are shown in Table 1 and in the Appendix.

As shown in $\mathrm{Cl}-\mathrm{SO}_{4}-\mathrm{HCO}_{3}$ chart, the chemical compositions of samples collected in the study area indicate the peripheral geothermal reservoir origin (Figure 3) (Doan Van Tuyen et al., 2014). The Na-K-Mg chart obtained from the study showed disequilibrium condition of a large proportion of the water, and the non-stop movement of geothermal water has been rising from the place near the heat source to surface.

One way to estimate the reservoir temperature is the use of series of formulas called geochemical thermometers (Arnorsson, 1985; Fournier, 1977, 1979; Powell and Cumming, 2010; Truesdell and Fournier, 1977). In this study the geochemical thermometers termed as Christobalite/Chalcedony, Na-K-Ca corrected $\mathrm{Mg}$, and $\mathrm{K} / \mathrm{Mg}$ were used. In general the temperature derived from the thermometers with more or less use of $\mathrm{Mg}$ component is always lower than the other one. In particular, some less reliable results indicated the value lower than the temperature of exposed water on the ground surface were eliminated from the results (Doan Van Tuyen et al., 2014 ).

The reservoir temperature obtained by the thermometer Na-K-Ca varied in a range 167$221{ }^{\circ} \mathrm{C}$, equivalent to the average temperature value of thermometer $\mathrm{Na} / \mathrm{K}$ and mixed model silica-enthalpy $\left(210^{\circ} \mathrm{C}\right)$ is more suitable, probably reflects the temperature of the geothermal reservoir (Table 1). 
Tran Anh Vu, et al./Vietnam Journal of Earth Sciences 39 (2017)

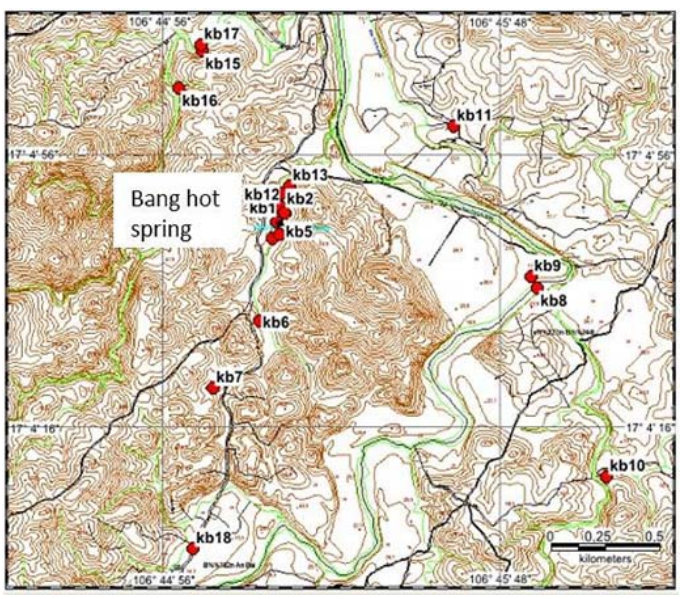

Figure 3. Locations of water sample collection in the area of Bang hot spring

The correlation between $\delta 18 \mathrm{O}$ and $\delta 2 \mathrm{H}$ of fluids is presented in Figure 5. The results obtained from the isotope analysis indicated mixed geothermal water with magmatic andesite origin. Both hot spring samples $\mathrm{M} 5(\mathrm{~Kb} 2), \mathrm{M} 7(\mathrm{~Kb} 5)$ are located close to the local meteoric line together with local groundwater M1 and rain M6 samples, suggesting that the thermal water discharging at the hot springs is mostly fed by shallow groundwater and rainy sources. This information confirmed the magmatic origin of the geothermal water in the study area (Figure 5). Mixing line in Bang hot spring distributing in higher level $\delta 2 \mathrm{H}$ than standard one is explained (e.g. Giggenbach, 1991) by evaporation of water from East Vietnam Sea embedded in the rock from ancient Long Dai sea. The cycle of rainy water circulation determined by ratio $3 \mathrm{H} 0 / 3 \mathrm{H}$ is around 38 years.

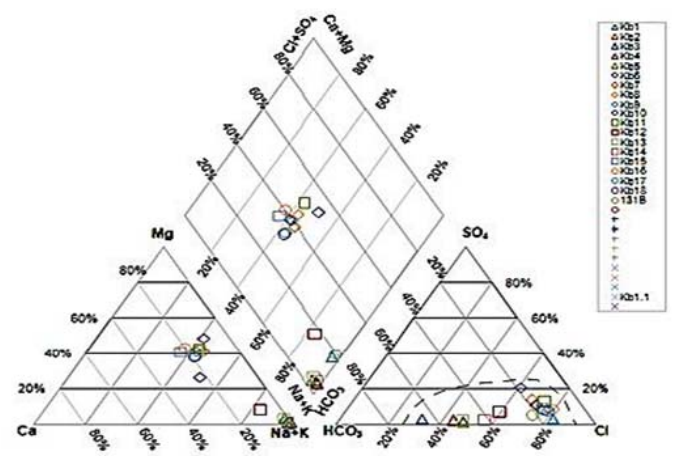

Figure 4. Chart $\mathrm{Cl}-\mathrm{SO}_{4}-\mathrm{HCO}_{3}$ for water samples in Bang hot spring

Table 1. Temperature of hot water samples and geothermal reservoir calculated by geochemical thermometers in area Bang

\begin{tabular}{|c|c|c|c|c|c|c|c|c|c|}
\hline \multirow[b]{2}{*}{$\begin{array}{c}\text { Index of } \\
\text { water } \\
\text { samples }\end{array}$} & \multirow[b]{2}{*}{$\begin{array}{l}\text { Coodinates of } \\
\text { site (lat, long) }\end{array}$} & \multirow[b]{2}{*}{$\begin{array}{c}\text { Temp of } \\
\text { water at } \\
\text { surface, T, } \\
{ }^{\circ} \mathrm{C}\end{array}$} & \multicolumn{7}{|c|}{ Calculated reservoir temperature, $\mathrm{T},{ }^{\circ} \mathrm{C}$ by geochem thermometer } \\
\hline & & & $\begin{array}{l}\text { Cristobalit } \\
\text { e/Chal- } \\
\text { cedony }\end{array}$ & Quartz & $\begin{array}{c}\mathrm{Na}-\mathrm{K}- \\
\mathrm{Ca}\end{array}$ & $\begin{array}{l}\mathrm{Na}-\mathrm{K}-\mathrm{Ca} \\
\mathrm{Mg} \text { corr }\end{array}$ & $\mathrm{Na} / \mathrm{K}(*)$ & $\begin{array}{c}\mathrm{K} / \mathrm{Mg} \\
\text { Giggen- } \\
\text { bach, } 1986\end{array}$ & $\begin{array}{l}\text { Mixed } \\
\text { model } \\
\text { Silic- } \\
\text { enthalpy }\end{array}$ \\
\hline$\overline{131 \mathrm{~B}}$ & $\begin{array}{l}106.83894 \\
17.067905\end{array}$ & 100 & $58 / 79$ & 109 & 167 & 87 & $137-175$ & 93 & \\
\hline KB1 & $\begin{array}{l}106.83955 \\
17.068915\end{array}$ & 96.29 & $57 / 78$ & 107 & 201 & 78 & $202-231$ & 97 & \\
\hline KB2 & $\begin{array}{l}106.80032 \\
17.076487\end{array}$ & 97.12 & $59 / 80$ & 109 & 197 & 148 & $174-208$ & 114 & 210 \\
\hline KB3 & $\begin{array}{l}106.75753 \\
17.09163\end{array}$ & 93.85 & $53 / 74$ & 104 & 186 & 133 & $186-221$ & 110 & \\
\hline KB4 & $\begin{array}{l}106.74872 \\
17.093137\end{array}$ & 90.07 & $61 / 82$ & 112 & 209 & 110 & $175-208$ & 106 & \\
\hline KB5 & $\begin{array}{l}106.71632 \\
17.096931\end{array}$ & 84.13 & $59 / 80$ & 110 & 187 & 34 & $162-196$ & 86 & \\
\hline
\end{tabular}

Note: Column with symbol $(*)$ is the range of temperature calculated by the 5 formulas - geochemical thermometer Na/K: Fournier, 1979; Truesdell, 1976; Tonani, 1980; Arnorsson, 1983; Nieva, 1987 


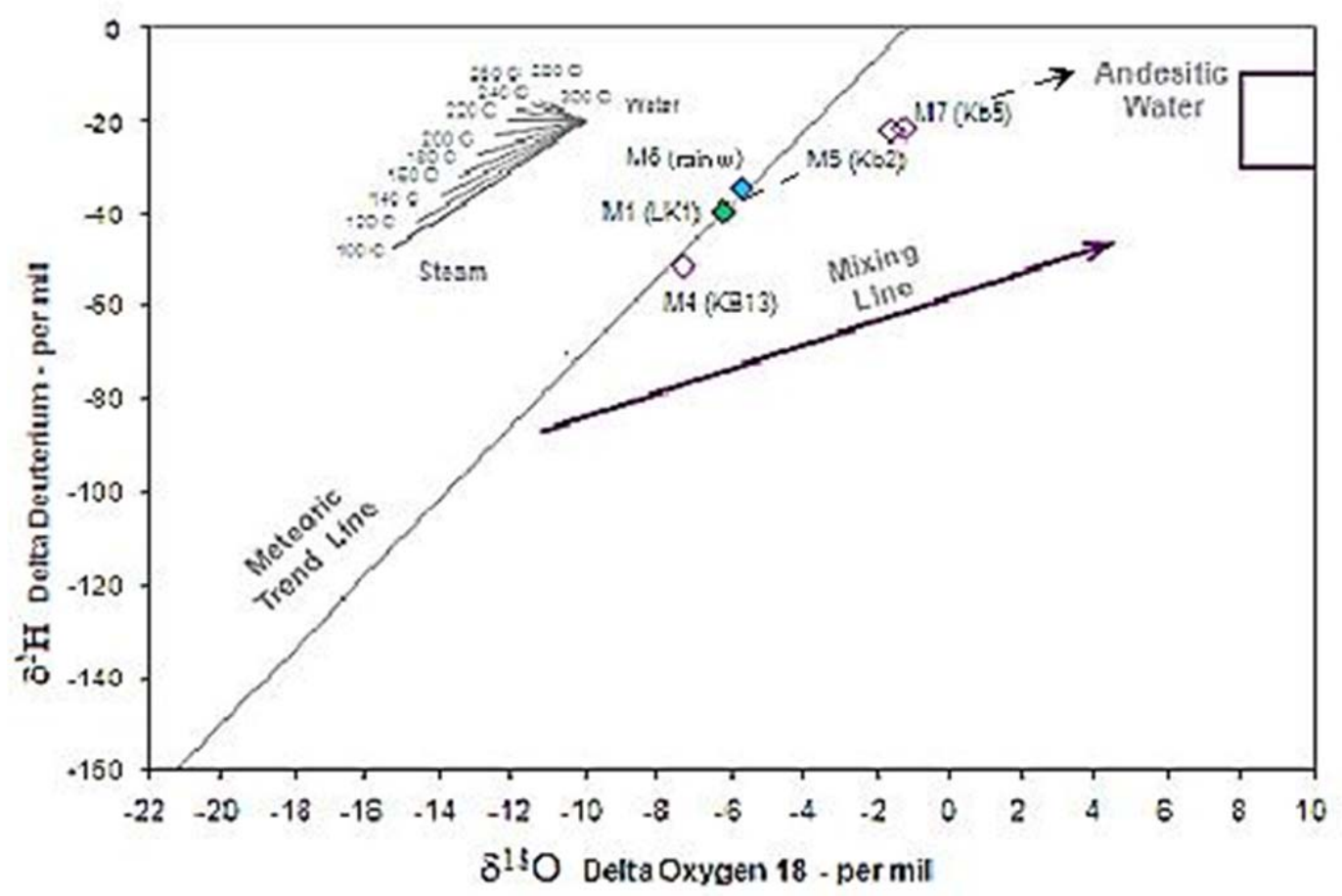

Figure 5. Diagram $\delta^{2} \mathrm{H}-\delta^{18} \mathrm{O}$ for water samples in Bang hot spring indicates andesite origin

\subsubsection{Geophysical data}

The data of geophysical surveys successfully identify the location, structural features of the geothermal system and reservoir.

The magnetotelluric (MT) survey was carried out in a dense network of measurement points (Figure 4, left). In this paper, only the results related to the indication of the geothermal reservoir are presented (Di Pippo, 2012, Munoz, 2014; IGA report, 2013; Williams et al., 2008). The low resistivity structure $(\rho \mathrm{k}<10 \mathrm{Ohm} . \mathrm{m})$ revealed at a depth of $Z=3 \mathrm{~km}$ from MT data in southern part of the area (Figure 6, right) suggested the location occupied the geothermal reservoir on the plane.

On the 2D resistivity structural model along B-B' and C-C' lines (Figure 7) the indication of geothermal reservoir is reflected by a very low resistivity zone (Doan Van Tuyen et al.,
2014; 2015). Thus, the structural feature of the geothermal system in the Bang area identified by the geophysical surveys is satisfied the worldwide conceptual model of a hydrogeothermal system of magmatic origin (Brikowski et al., 2001; Wang and Horne, 1999) by both structural elements as well as its physical properties (Figure 7), such that, (1) the clay cap detected at depth about $2-3 \mathrm{~km}$ plays a role in preventing the heat transfer from the geothermal reservoir to subsurface rock layers; (2) beneath the cap is located the geothermal reservoir with bottom boundary reaching the depth up to 6-7 km. The results reveal that the exposed Bang hot water spring belongs to the northern peripheral edge of the reservoir; and (3) deeper in the crust the low resistivity structure revealed from depth about 10-12 km can be interpreted as an intrusive body (hot magma?), which plays a role of the heat supply source for the geothermal reservoir. 


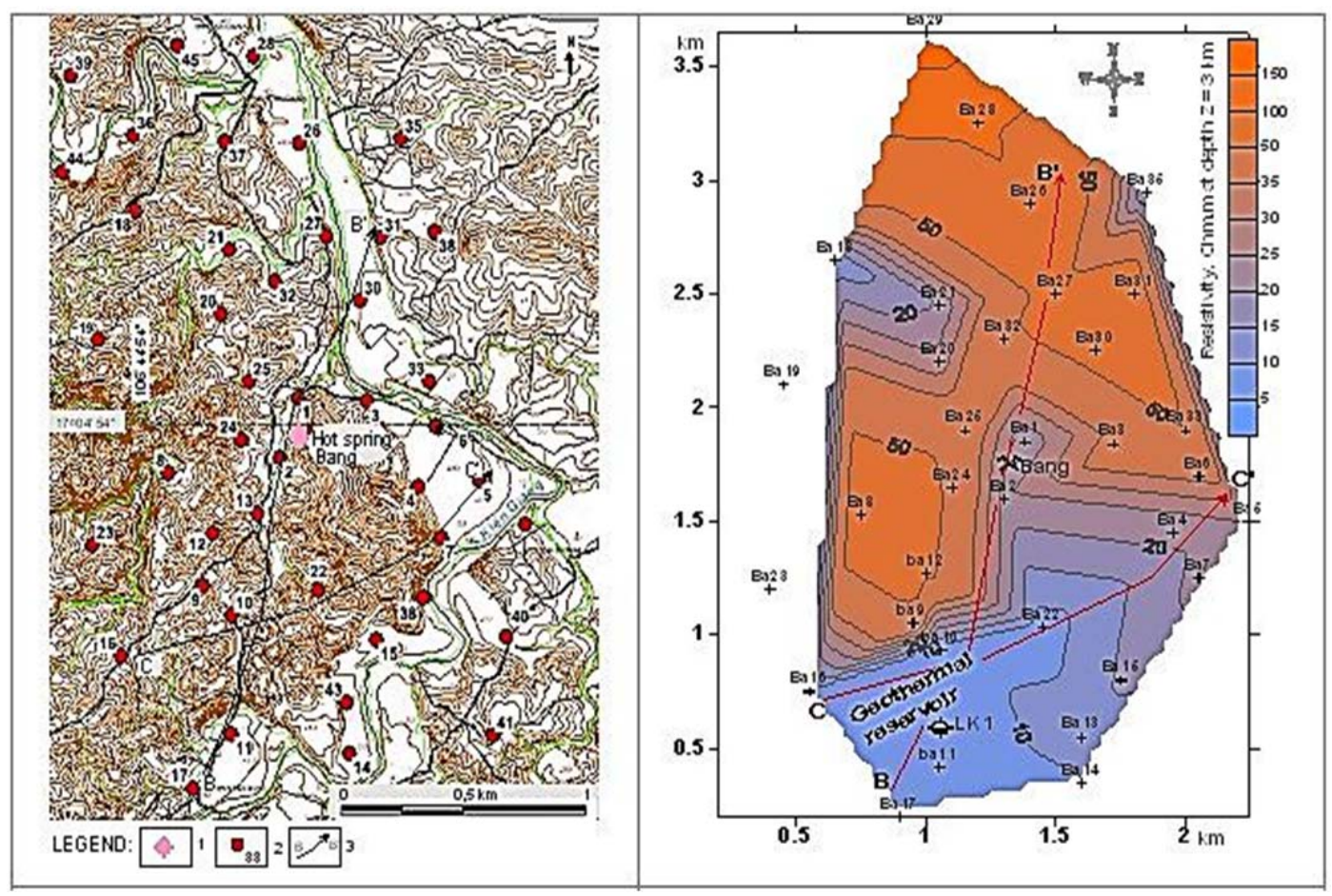

Figure 6. Left: Distribution of MT observation in area Bang hot spring (Legend: 1 - location of hot spring; 2 - point of MT measurement; 3 - MT cross-section); Right: resistivity countour at depth $Z=-3 \mathrm{~km}$ indicates geothermal reservoir in Bang area (Legend: Ba10 - Index site of MT observation; B-B', C-C': Line of MT resistivity crosssection; LK1- site of drill hole)

\subsubsection{Subsurface geothermal data}

The results of in-situ temperature measurements conducted along depths of the borehole LK1 (see Figure 6, right) just after the end of drilling (24 November 2014) and repeated about 6 months later (9 May 2015) is illustrated in Figure 8. The average of the geothermal conductivity of the drilling core samples measured in the laboratory is about $2.1 \mathrm{~W} / \mathrm{m} . \mathrm{K}$ The temperature gradient and heat flow calculated using the repeated $\log$ data reached the abnormal values of about $4.1^{\circ} \mathrm{C} / 100 \mathrm{~m}$ and $83.6 \mathrm{~mW} / \mathrm{m}^{2}$, respectively. The reservoir temperature was also estimated by applying 1D temperature modeling techniques (Gupta, 2007; Lucak C.V., 1988; Carol A. Stein, 1995). The B-B' profile going through the borehole site LK1 was chosen for calculation. The crustal structural parameters used for modeling are derived from magnetotelluric data (Doan Van Tuyen et al., 2015a, 2015b) under consideration of regional structures obtained in the previous studies (Bui Cong Que, Nguyen Kim Lap, 1992; Dinh Van Toan et al., 2015), the geothermal properties (surface heat flow, thermal conductivity of rocks) from the measurements of samples taken from the shallow drilling hole LK1, and properties of deeper geological horizontals were selected from handbooks (Truong Thu Huong (Ed.), 2006; Dortman,1984; Robertson Eugene, 1988). The temperature structural model obtained from the calculation indicates the temperature reaching $2000^{\circ} \mathrm{C}$ in the upper 
section of the expected geothermal reservoir at depth about $3 \mathrm{~km}$ (Figure 9), that appears similar to the value of reservoir temperature determined by most geochemical thermometers in this study. Based on these results, the site LK1 can be selected for test drilling in the next phase to evaluate the possibility of geothermal energy exploitation.

2D-MT resistivity cross-section along line B-B' in Bang
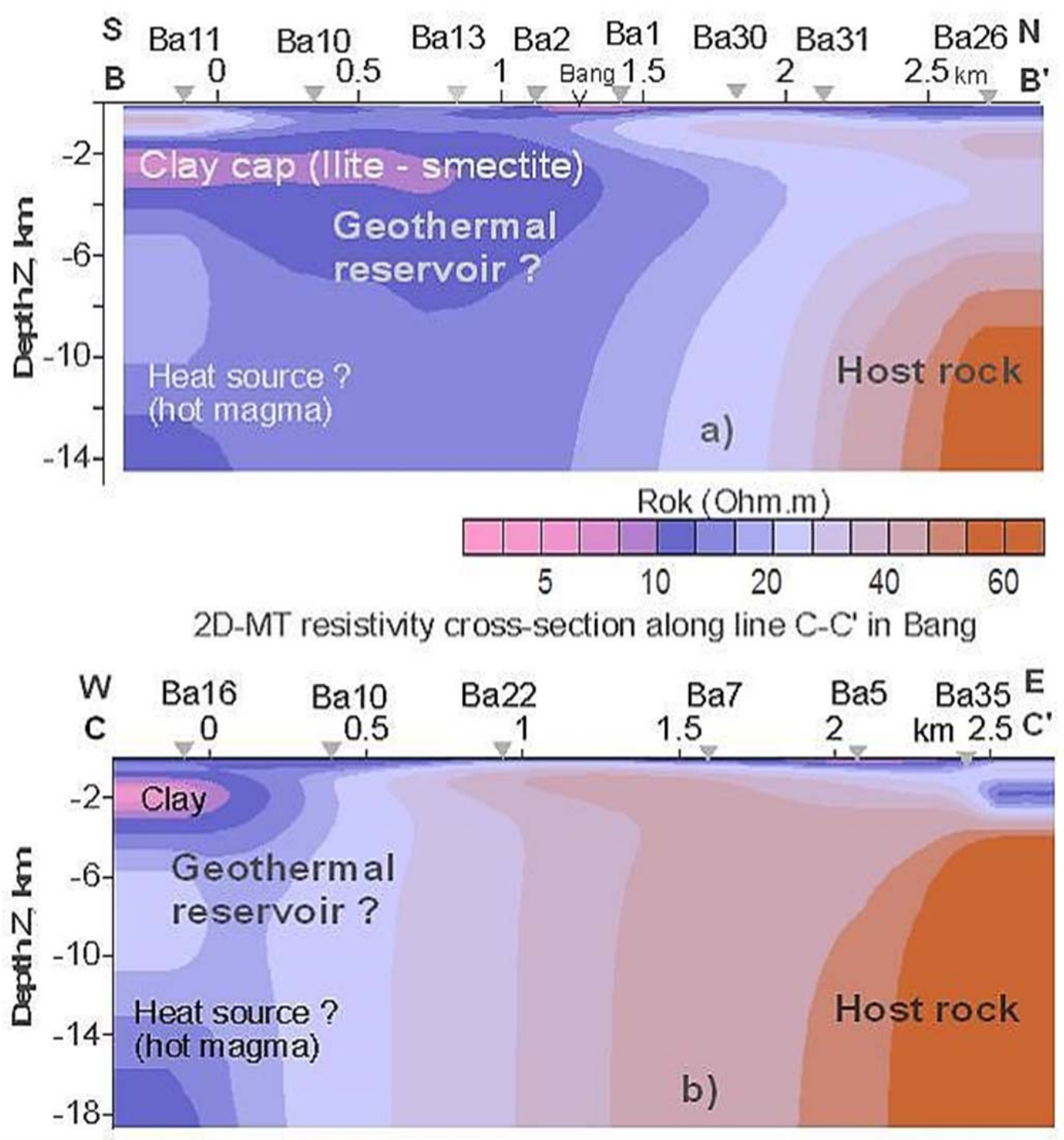

Figure 7. MT Resistivity cross-section along lines B-B' (a) and C-C' (b) reflecting structure of geothermal reservoir. Legend: Ba10- Site and number of MT survey 
Tran Anh Vu, et al./Vietnam Journal of Earth Sciences 39 (2017)

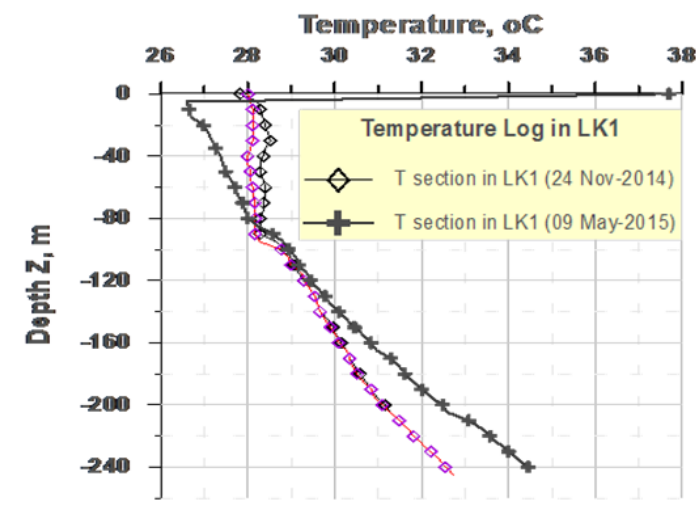

Figure 8. Temperature log at site of drilling hole LK1
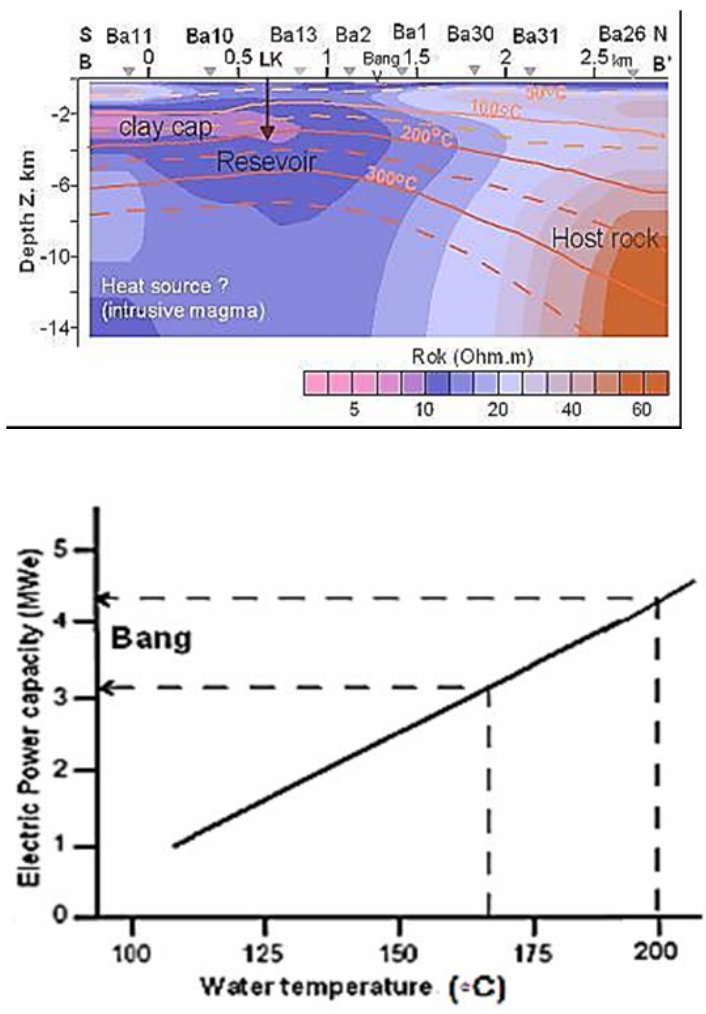

$\leftarrow$ Figure 9. Temperature model of geothermal reservoir in area Bang hot spring

Legend: Ba10- Site and number of MT survey; LK- site of drilling hole

2.2.5. Estimation of electric power of the geothermal reservoir in the Bang spring area

Based on the structures and temperature of the reservoir $\left(>167-200^{\circ} \mathrm{C}\right)$, the flow rate of geothermal fluid of 401/s defined from field observation, the electric power to be generated by the reservoir was estimated. A simple experimental graphical technique using the correlation between reservoir temperatures and the flow rate of water from the source (Chandrasekharam, 2008) was used. The exploitation capacity estimated in a range of 3-4 MWe (Figure 10) is derived from the results characterizing for worldwide statistical data: stable electricity generation of one geothermal source in the fault-based nonactive volcanic region not exceeding $10 \mathrm{MWe}$ (Williams, et al., 2008).

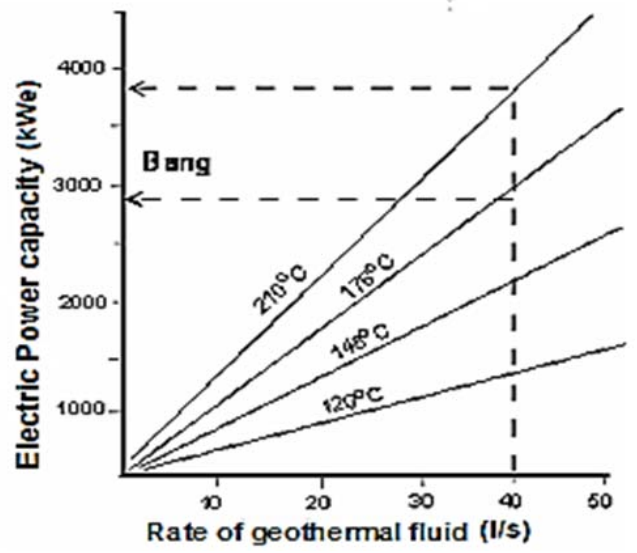

Figure 10. Estimation of Electric power capacity of geothermal reservoir in area Bang hot spring

The estimated capacity of electricity generation and the similarity of the parameters of the expected geothermal reservoir in the Bang area such as reservoir water origin, structural elements, temperature to the parameters of the Worldwide conceptual model of a hydro-geothermal system is the reliable basis to suggest the test drilling to the depth of $2.5 \mathrm{~km}$ in the next plan. The data generated in the test-drilling step will be 
reflected the actual state of the geothermal reservoir, that can be used to propose the future plan for construction of a pilot geothermal power plant.

\section{Conclusions}

Among more than 280 exposed hot water sources discovered in Vietnam, the geothermal sources with the indication of magmatic origin reflecting from their geochemical characteristics, geologicaltectonic conditions, and geothermal regime are concentrated in the Central Region. Since the geothermal sources of this type were recognized as aspiring objects for electricity power generation, therefore, explorations to develop electrical energy in the coming time should be better to concentrate in the Central Region.

The conducted exploration surveys including geophysical and geochemical techniques applied in this study effectively defined the location, structural feature, thermal state as well as the origin of the geothermal reservoir in the Bang hot spring area. The similarity in the parameters of the reservoir to the Worldwide conceptual model of a hydro- geothermal system is a good basis for deployment of a test drilling in the next phase of the geothermal program.

The successful determination of the geothermal reservoir in the Bang area indicates a correct methodology and techniques chosen for the exploration and data acquisition. The techniques used and the practical experiences accumulated in this study by the participants can serve as effective tools to assess the other geothermal perspective objects in different locations in order to establish the database of geothermal energy potential and propose the strategy for geothermal energy exploitation as a renewable energy resource in Vietnam.

\section{Acknowledgments}

This work was supported by the Vietnam National Program "Scientific Research and Technology for disaster prevention, environmental protection and rational use of natural resources" to project coded KC08.16/11-15. The first author would like to thank the leaders of this Project for providing material to his doctoral research.

\section{References}

Arnorsson S., 1985. The use of mixing models and chemical geothermometers for estimating underground temperatures in geothermal systems. J. Volcan. Geoth. Res., 23, 209-335.

Bertani R., 2015. Geothermal Power Generation in the World 2010-2014 Update Report. Proceedings World Geothermal Congress 2015 Melbourne, Australia, 19-25, April 2015, 19p.

Brikowski T., Norton D., Blackwell D., 2001. Final Report: Natural State Models of The Geysers Geothermal System, DOE Contract DE-FG0798ID13677. December 31.

Bui Cong Que, Nguyen Kim Lap, 1992. Structure of the Earth's crust and seismicity in the territory of Vietnam. The Book published by Vietnam Academy of Science, 148p.

Carol A. Stein, 1995. Heat flow of the Earth, in the Book "Global Earth Physics" edited by AGU1995, 144-158.

Chandrasekharam D., Jochen Bundschuh, 2008. LowEnthalpy geothermal resources for power generation. Taylor \& Francis Group, London, UK, $172 p$.

Di Pippo R., 2012. Geothermal Power plant. Principles, applications, case studies. $3^{\text {rd }}$ edition. Elsevier, 579p.

Dinh Van Toan, Nguyen Trong Yem, Trinh Viet Bac, 1996. The preliminary results of heat flow study in South Vietnam. Vietnam Journal of Earth Sciences, 18, 74-79.

Dinh Van Toan, Lai Hop Phong, Tran Anh Vu, Nguyen Thi Hong Quang, 2015. Study on the Earth's crustal structure in the area of Song Tranh and it's adjacents. Vietnam Journal of Earth Sciences, 37, 127-138 (in Vietnamese). DOI: 10.15625/08667187/37/2/7368.

Doan Van Tuyen, Tran Anh Vu, Nguyen Thi Kim Thuong, 2014. Geochemical characteristics of geothermal water sources on the territory of Vietnam. Proceedings, Thirty-Eighth Workshop on Geothermal Reservoir Engineering - Stanford 
Tran Anh Vu, et al./Vietnam Journal of Earth Sciences 39 (2017)

University, California, February 24-26, 2014; SGPTR-202, 8p.

Doan Van Tuyen, Tran Anh Vu, Lai Hop Phong, Pham Ngoc Dat, Le Van Si, Dinh Van Toan, Nguyen Thi Hong Quang, 2015. Results of magnetotelluric survey for studying geothermal system in the Bang area, Quang Binh Province. Vietnam Journal of Earth Sciences, 37(2), 48-56 (in Vietnamese). DOI: 10.15625/0866-7187/37/1/6553.

Doan Van Tuyen, Tran Anh Vu, Lai Hop Phong, Pham Ngoc Dat, Dinh Van Toan, Le Van Si, 2015. Structural feactures of geothermal Field from Magnetotelluric Survey in Nothern Cenral region of Vietnam. Proceedings World geothermal Congress 2015, Melbourne, Australia, 19-25 April 2015, 6p.

Flynn T., Quy H.H., 1997. Assessment of the geothermal resources of Socialist Republic of Vietnam. Geothermal resources Council Transactions, 21, 341-345.

Fournier R.O., 1977. Chemical geothermometers and mixing models for geo-thermal systems. Geothermics, 5, 41-50.

Fournier R.O. and Potter R.W. II, 1979. Magnesium correction to the Na-K-Ca chemical geothermometer. Geochim. Cosmochim. Acta, 43, 1543-1550.

Fournier R.O., 1979. A revised equation for the Na-K geothermometer. Geo-thermal Resource Council Transections, 3, 221-224.

GeothermEx, 2004. New geothermal site identification and qualification. Consultant report for California Energy Commission, Richmond, CA.

Giggenbach W.F., 1991. Isotopic composition of geothermal water and steam discharges. In D'Amore, F. (editor), Application of Geochemistry in Geothermal Reservoir Development. UNITAR/UNDP publication, Rome, 253-273.

Gupta H., 2007. Geothermal Energy: An Alternative resource for the $21^{\text {st }}$ Century. Elsevier PH. ISBN-13: 978-0-444-52875-9. 285p.

He Lijuan, 1999. Analysis of heat flow along a transect across the South China Sea. Geothermal Training Pro-gramme, Reports, 5, 125-140.

IGA report, 2013. Geothermal Exploration best practices: A Guide to resource data collection, analysis, and presentation for Geothermal projects.
Lucak C.V., 1988. Heat flow in the Continental rift zones. Publish House "Nauka" Soviet Union Academy of Science, Novosibirsk Branch, 198p (in Russian language).

Munoz G., 2014. Exploring for Geothermal Resources with Electromagnetic Methods, Surv Geophys, 35, 101-122.

Nguyen Hoang, Flower M., Pham Tich Xuan, 1996. The petrology of Late Kainozoic Basalts in Vietnam. In monography "Geology and Natural resource", P.H. Science and Technology, Ha Noi, 142-155 (in Vietnamese).

Nguyen Xuan Han et al., 1991. Young volcano activity in Vietnam East Sea. In monography "Geology and Natural resource", PH Science and Technology, Ha Noi, 84-96 (in Vietnamese).

Phan Cu Tien et al., 1991. Geology of Cambodia, Laos and Vietnam. Geological survey of Vietnam, $2^{\text {nd }}$ edition. Hanoi, 158p.

Powell T. and Cumming M., 2010. Spreadsheets for Geothermal Water and gas geochemistry. Proceedings, Thirty-Fifth Workshop on Geothermal Reservoir Engineering, Stanford University, Stanford, California, February 1-3, SGP-TR-188, 10p.

Tran Anh Vu, Dinh Van Toan, Doan Van Tuyen, Lai Hop Phong, Duong Thi Ninh, Nguyen Thi Hong Quang, Pham Ngoc Dat, 2016. Utilization of seismic refraction data for study of structure of Bang Hotwater source, Le Thuy, Quang Binh. Vietnam Journal of Earth Sciences, 38(4), 393-408. DOI: $10.15625 / 0866-7187 / 38 / 4 / 8994$.

Tran Huyen, Truong Minh, Nguyen Tien Bao, 1999. On the geothermal regime in the sedimentary basins, continental shelf of Vietnam. Journal of economic geology and mineral materials, Publication of of the Department of geology and minerals 18, 16-25 (in Vietnamese).

Tran Van Tri (Project manager), et al., 2004. Map of geology and mineral resources of Vietnam on scale $1: 1,000,000$. Publication of the Department of Geology and mineral recources of Vietnam, Hanoi (in Vietnamese).

Truesdell A.H. and Fournier R.O., 1977. Procedure for estimating the tempera-ture of a hot water component in a mixed water using a plot of dissolved silica vs enthalpy. US Geol. Survey J. Res., 5, 49-52. 
Vietnam Journal of Earth Sciences, 39(3), 289-302

Truong Thu Huong (Ed.), Vo Bich ngoc, Nguyen Duc Thang, Pham Toan, Nguyen Huu Tri, 2006. Online Handbook: "Physical properties of Rocks and Minerals in Vietnam. Publication of Northern Vietnam Geological Maping Division, Ha Noi, 546p (in Vietnamese).

Vo Cong Nghiep (Ed.), 1998. Geothermal resource in Vietnam and perspectives of their use for energy purposes. Monography Published by Vietnam
Department for Geological and mineral resource. Hanoi, 300p (in Vietnamese).

Wang C.T., and Horne R.N., 1999. Boiling Flow in a Horizontal Fracture, Geothermics, 29, 759-772.

Williams C.F., Reed M.J. and Mariner R.H., 2008. A review of methods applied by the U.S. Geological Survey in the assessment of identified geothermal resources, U.S. Geol. Survey Open-File Report 2008-1296, 27p. [http://pubs. usgs.gov/ of/2008/ 1296/].

\section{APPEDIX}

Table 1. Chemical components in the area of hot spring Bang

\begin{tabular}{|c|c|c|c|c|c|c|c|c|c|c|c|c|c|c|c|c|c|c|}
\hline \multirow[b]{2}{*}{$\mathrm{NN}$} & \multirow[b]{2}{*}{ Parameters } & \multirow[b]{2}{*}{ Unit } & \multicolumn{16}{|c|}{ Index of samples/value or content } \\
\hline & & & KB1 & KB2 & KB3 & KB4 & KB5 & KB6 & KB7 & KB8 & KB9 & KB10 & KB11 & KB12 & KB13 & KB14 & KB15 & KB16 \\
\hline$\overline{1}$ & Temperature & ${ }^{\circ} \mathrm{C}$ & 96.29 & 97.12 & 93.85 & 90.07 & 84.13 & 27.10 & 28.90 & 30.3 & 30.8 & 29.7 & 32.4 & $\overline{68.43}$ & 78.1 & 62.0 & 30.2 & 34.5 \\
\hline 2 & Soluble sludge & $\mathrm{mg} / 1$ & 378 & 450 & 437 & 448 & 442 & 93.4 & 54 & 56 & 39 & 58 & 47 & 243.5 & 413.5 & 437.0 & 51 & 51 \\
\hline 3 & $\mathrm{pH}$ & & 8.47 & 8.51 & 8.37 & 8.03 & 8.45 & 5.67 & 6.84 & 6.51 & 6.06 & 6.5 & 6.71 & 6.63 & 8.43 & 8.28 & 7.84 & 6.89 \\
\hline 4 & Total stiffness & $\mathrm{mg} / 1$ & 0.18 & 0.10 & 0.16 & 0.12 & 0.32 & 0.66 & 0.40 & 0.40 & 0.30 & 0.48 & 0.26 & 0.60 & 0.28 & 0.16 & 0.50 & 0.50 \\
\hline 5 & $\mathrm{EC}$ & $\mathrm{mS} / \mathrm{m}$ & 58 & 59.7 & 58.4 & 55.5 & 48.60 & 11.6 & 3.7 & 3.7 & 3.5 & 3.9 & 6.4 & 25.4 & 48.6 & 57 & 6.0 & 3.80 \\
\hline 6 & $\mathrm{HCO}_{3}{ }^{-}$ & $\mathrm{mg} / \mathrm{l}$ & 294.9 & 421.2 & 419.44 & 419.2 & 420.1 & 42.8 & 30.0 & 30.0 & 21.96 & 34.16 & 26.60 & 185.2 & 385.28 & 407.0 & 31.72 & 31.72 \\
\hline 7 & $\mathrm{CO}_{2}$ free & $\mathrm{mg} / \mathrm{l}$ & 0 & 0 & 0 & 0 & 0 & 35.95 & 8.36 & 8.36 & 9.18 & 9.18 & 8.36 & 8.36 & 0 & 0 & 0.42 & 5.42 \\
\hline 8 & $\mathrm{Ca}^{2+}$ & $\mathrm{mg} / 1$ & 1.20 & 1.20 & 2.40 & 0.40 & 1.60 & 6.00 & 2.00 & 2.00 & 1.80 & 1.60 & 2.80 & 6.00 & 2.00 & 1.20 & 3.60 & 3.20 \\
\hline & $\mathrm{Mg}^{2+}$ & $\mathrm{mg} / \mathrm{l}$ & 46 & 0.50 & 0.73 & 0.89 & 2.92 & 4.37 & 3.65 & 3.65 & 2.67 & 4.86 & 4.86 & 3.65 & 2.19 & 1.21 & 3.89 & 4.13 \\
\hline 10 & & $\mathrm{mg} / \mathrm{l}$ & 29.80 & 5.10 & 3.52 & 4.52 & 3.71 & 17.04 & 7.95 & 9.37 & 6.53 & 9.09 & 11.36 & 13.45 & 4.95 & 7.10 & 7.95 & 9.94 \\
\hline 11 & & $\mathrm{mg} / \mathrm{l}$ & 12.77 & 13.33 & 14.40 & 13.42 & 11.57 & 1.33 & 0.62 & 1.41 & 0.71 & 1.62 & 2.67 & 6.38 & 12.03 & 13.22 & 1.05 & 1.17 \\
\hline 12 & $\mathrm{Na}^{+}$ & $\mathrm{mg} / \mathrm{l}$ & 119.5 & 152.0 & 146.7 & 151.8 & 149.45 & 15.06 & 7.25 & 6.10 & 4.84 & 6.83 & 7.76 & 66.85 & 133.05 & 147.6 & 6.05 & 6.11 \\
\hline 13 & $\mathrm{NO}_{2}^{-}$ & $\mathrm{mg} / 1$ & 0.001 & $<0.001$ & 0.001 & $<0.001$ & 0.001 & 0.038 & 0.015 & 0.027 & 0.013 & 0.025 & 0.153 & 0.016 & $<0.001$ & $<0.001$ & $<0.001$ & $<0.001$ \\
\hline 14 & $\mathrm{NO}_{3}{ }^{-}$ & $\mathrm{mg} / \mathrm{l}$ & 0.005 & $<0.001$ & $<0.001$ & 0.001 & $<0.001$ & 0.95 & 0.15 & 0.76 & 0.083 & 0.69 & 1.89 & 0.426 & 0.001 & $<0.001$ & $<0.001$ & 0.394 \\
\hline
\end{tabular}

Table 1 (continue table 1). Chemical components in area of hot spring Bang

\begin{tabular}{|c|c|c|c|c|c|c|c|c|c|c|c|c|c|c|c|c|c|c|}
\hline \multirow{3}{*}{$\mathrm{NN}$} & \multirow[b]{2}{*}{ Parameters } & \multirow[b]{2}{*}{ Unit } & \multicolumn{16}{|c|}{ Index of samples/value or content } \\
\hline & & & KB1 & KB2 & KB3 & KB4 & KB5 & KB6 & KB7 & KB8 & KB9 & KB10 & KB11 & KB12 & KB13 & KB14 & KB15 & KB16 \\
\hline & Temperature & ${ }^{\circ} \mathrm{C}$ & 96.29 & 97.12 & 93.85 & 90.07 & 84.13 & 27.10 & 28.90 & 30.3 & 30.8 & 29.7 & 32.4 & 68.43 & 78.1 & 62.0 & 30.2 & 34.5 \\
\hline 15 & $\mathrm{NH}_{4}^{+}$ & $\mathrm{mg} / \mathrm{l}$ & 1.27 & 0.40 & 0.42 & 0.40 & 0.42 & 0.24 & 0.20 & $\overline{0.22}$ & 07 & $\overline{22}$ & $\overline{0.72}$ & 0.34 & 0.53 & $\overline{0.40}$ & 0.05 & 0.015 \\
\hline 16 & & & 0.60 & & 0. & 0.15 & 0.29 & $<0.1$ & 0.01 & $<0.1$ & 0.1 & $<0.1$ & $<0.1$ & 2.4 & 0.86 & 0.86 & $<0.1$ & $<0.1$ \\
\hline 17 & Total & $\mathrm{mg} / \mathrm{l}$ & 6.0 & 4.0 & 4.0 & 2.0 & 4.0 & $<0.1$ & 0.015 & $<0.1$ & $<0.1$ & $<0.1$ & $<0.1$ & 4.0 & 12.0 & 12.0 & $<0.1$ & $<0.1$ \\
\hline 18 & $\mathrm{SO}_{4}{ }^{2-}$ & $\mathrm{mg} / \mathrm{l}$ & 8.86 & 7.49 & 10.26 & 7.81 & 5.40 & 14.67 & 4.21 & 5.84 & 2.58 & 4.91 & 5.37 & 12.25 & 7.35 & 7.47 & 3.51 & 3.51 \\
\hline 19 & $\mathrm{PO}_{4}{ }^{3-}$ & $\mathrm{mg} / \mathrm{l}$ & 0.001 & 0.001 & 1.25 & 0.001 & 0.012 & 0.015 & 0.015 & $<0.001$ & $<0.001$ & 0.013 & 0.005 & 2.51 & $<0.001$ & $1<0.001$ & 0.015 & $<0.001$ \\
\hline 20 & Total Fe & $\mathrm{mg} / \mathrm{l}$ & $<0.001$ & 0.001 & $<0.001$ & $<0.001$ & $<0.001$ & 0.756 & 0.352 & 0.51 & $<0.001$ & & 1.25 & 1.73 & 1.05 & 0.01 & 0.125 & 0.15 \\
\hline 21 & $\mathrm{SiO}_{2}$ & $\mathrm{ng} / \mathrm{l}$ & 55.85 & 58.23 & 51.93 & 61.21 & 58.91 & 15.37 & 16.05 & 12.65 & 9.93 & & 9.59 & 41.22 & 59.25 & 58.57 & 9.25 & 7.55 \\
\hline 22 & $\mathrm{Mn}$ & $\mathrm{mg} / \mathrm{l}$ & 0.007 & 0.003 & 0.001 & 0.005 & 0.041 & 0.182 & 0.009 & 0.005 & 0.007 & 0.003 & 0.005 & 0.041 & 0.001 & 0.025 & 0.017 & 0.013 \\
\hline 23 & $\mathrm{Zn}$ & $\mathrm{mg} / \mathrm{l}$ & 0.002 & & 0.0 & 0.002 & 0. & 0.074 & 0.007 & 0.023 & 0.025 & 0. & 0.012 & 0.082 & 0.096 & 0.055 & 0.031 & 0.008 \\
\hline 24 & $\mathrm{~Pb}$ & $\mu \mathrm{g} / \mathrm{l}$ & & & & & & 3.11 & 2. & & & & 2.23 & 2.46 & 1.63 & 1.80 & 2.03 & 1.88 \\
\hline 25 & As & $\mu \mathrm{g} / 1$ & 1.25 & & 2.50 & & & 4.89 & 2.15 & 1.05 & & & 1.37 & 1.65 & 1.25 & 2.05 & 1.81 & 3.05 \\
\hline 26 & $\mathrm{Cd}$ & $\mu \mathrm{g} / 1$ & 0.137 & 0.189 & 0.134 & 0.137 & 0.135 & 0.212 & 0.152 & 0.356 & 0.151 & 0.141 & 0.215 & 0.18 & 0.171 & 0.179 & 0.143 & 0.134 \\
\hline
\end{tabular}

Table 2. Content of stable $\delta^{18} \mathrm{O}-\delta^{2} \mathrm{H},{ }^{3} \mathrm{H}$ of water samples in the area of hot spring Bang

\begin{tabular}{|c|c|c|c|c|c|c|c|c|}
\hline NN & $\begin{array}{l}\text { Index of } \\
\text { samples }\end{array}$ & Latitude & Longtitude & $\begin{array}{c}\text { Temperature } \\
\left({ }^{\circ} \mathrm{C}\right)\end{array}$ & $\begin{array}{c}\delta^{18} \mathrm{O} \\
\left(\%{ }_{0} \mathrm{SMOW}\right) \\
\end{array}$ & $\begin{array}{c}\delta^{2} \mathrm{H} \\
(\% \circ \mathrm{SMOW})\end{array}$ & $\begin{array}{c}{ }^{3} \mathrm{H} \\
\text { (T.U) }\end{array}$ & Note \\
\hline 1 & M1 & $17^{\circ} 4^{\prime} 10.85$ & $106^{\circ} 45^{\prime} 9.00$ & 27.1 & -6.2 & -39.3 & 10.0 & Drill hole LK1 $(250 \mathrm{~m})$ \\
\hline 2 & M2 & $17^{\circ} 4^{\prime} 47.70$ & $106^{\circ} 45^{\prime} 13.37$ & 30.5 & -6.4 & -42.1 & 11.1 & Drill hole LK $(40 \mathrm{~m})$ \\
\hline 3 & M4 & $17^{\circ} 4^{\prime} 46.93$ & $106^{\circ} 45^{\prime} 16.14$ & 78.1 & -7.3 & -51.4 & 10.2 & Exposed hot water (Kb13) \\
\hline 4 & M5 & $17^{\circ} 4^{\prime} 49.78$ & $106^{\circ} 45^{\prime} 17.45$ & 97.12 & -1.6 & -22.2 & 0.5 & Exposed hot water $(\mathrm{Kb} 2)$ \\
\hline 5 & M7 & $17^{\circ} 4^{\prime} 53.72$ & $106^{\circ} 45^{\prime} 17.82$ & 84.13 & -1.3 & -21.4 & nd & Exposed hot water (Kb5) \\
\hline 6 & M6 & $17^{\circ} 4^{\prime} 49.78$ & $106^{\circ} 45^{\prime} 17.45$ & 25.0 & -5.7 & -34.2 & 4.3 & Rainy water \\
\hline
\end{tabular}


Tran Anh Vu, et al./Vietnam Journal of Earth Sciences 39 (2017)

Table 3. Dating of water by isotope ${ }^{3} \mathrm{H}$ in area of hot spring Bang

\begin{tabular}{|c|c|c|c|c|c|c|c|c|}
\hline NN & $\begin{array}{l}\text { Index of } \\
\text { samples }\end{array}$ & Latitude & Longtitude & $\begin{array}{c}\text { Temperature } \\
\left({ }^{\circ} \mathrm{C}\right) \\
\end{array}$ & $\begin{array}{c}{ }^{3} \mathrm{H}_{\mathrm{o}}(\mathrm{T} . \mathrm{U}) \\
\text { Rainy water }\end{array}$ & ${ }^{3} \mathrm{H}(\mathrm{T} . \mathrm{U})$ & $t(1963) \pm$ year & Note \\
\hline 1 & M1 & $17^{\circ} 4^{\prime} 10.85$ & $106^{\circ} 45^{\prime} 9.00$ & 27.1 & 4.3 & 10.0 & 14.93 & Drill hole LK1 (250 m) \\
\hline 2 & M2 & $17^{\circ} 4^{\prime} 47.70$ & $106^{\circ} 45^{\prime} 13.37$ & 30.5 & 4.3 & 11.1 & 16.77 & Drill hole LK (40 m) \\
\hline 3 & M4 & $17^{\circ} 4^{\prime} 46.93$ & $106^{\circ} 45^{\prime} 16.14$ & 78.1 & 4.3 & 10.2 & 15.28 & Exposed hot water (Kb13) \\
\hline 4 & M5 & $17^{\circ} 4^{\prime} 49.78$ & $106^{\circ} 45^{\prime} 17.45$ & 97.12 & 4.3 & 0.5 & -38.07 & Exposed hot water (Kb2) \\
\hline 5 & M7 & $17^{\circ} 4^{\prime} 53.72$ & $106^{\circ} 45^{\prime} 17.82$ & 84.13 & 4.3 & nd & nd & Exposed hot water (Kb5) \\
\hline 6 & M6 & $17^{\circ} 4^{\prime} 49.78$ & $106^{\circ} 45^{\prime} 17.45$ & 25.0 & 4.3 & 4.3 & 0 & Rainy water \\
\hline
\end{tabular}

Note: nd 